\title{
TEACHER'S PEDAGOGY COMPETENCE AND CHALLENGES IN IMPLEMENTING INCLUSIVE LEARNING IN SLOW LEARNER
}

\author{
Mumpuniarti Mumpuniarti", Rendy Roos Handoyo, Diajeng Tyas Pinrupitanza, Dewi \\ Barotuttaqiyah \\ Universitas Negeri Yogyakarta, Indonesia \\ *e-mail:mumpuni@uny.ac.id
}

\begin{abstract}
Regular teacher training for schools implementing inclusive education is expected to affect the teachers mastery of learning competency. The results of the training need to be examined to determine some aspects of competency that need to be trained further, so that it is beneficial to an ideal inclusive education. This study aims to describe regular teachers most important aspects of competency, as well as their obstacles and challenges in implementing learning in inclusive schools. The research instrument consisted of 21 closed-ended questions and 4 open-ended questions. The data from the 21 closed questions were analyzed using percentage of answers from respondents, and respondents' answers to the open-ended questions were analyzed using the categorization of the challenges faced by teachers for inclusive learning. The findings from the study shows that the inclusive teachers possessed the pedagogical competence to help them face the diversity of the students from various aspects; the regular teachers were able to manage the diverse learning needs; the regular teacher competence to help slow-learners was able to change abstract concepts into concrete forms; the regular teachers found some obstacles in managing students diversity; and the regular teachers challenges in implementing inclusive education included diverse teaching methods, competence to modify learning, and professional improvement achievement.
\end{abstract}

Keywords: competence pedagogy, teacher challenges, inclusive, slow-learner

\section{KOMPETENSI PEDAGOGI GURU DAN TANTANGAN PELAKSANAAN PEMBELAJARAN INKLUSIF PADA SLOW LEARNER}

\begin{abstract}
Abstrak: Pelatihan guru regular bagi sekolah penyelenggara pendidikan inklusi diharapkan memberi efek penguasaan kompetensi pembelajaran. Hasil pelatihan perlu diteliti untuk memutuskan aspek kompetensi yang perlu dilatih lebih lanjut sehingga bermanfaat bagi terselenggaranya pendidikan inklusif secara ideal. Penelitian ini bertujuan mendeskripsikan aspek kompetensi yang paling utama menjadi kekuatan guru reguler, kendala, dan tantangan yang dihadapi dalam melaksanakan pembelajaran di sekolah inklusif. Instrumen penelitian terdiri atas 21 butir pertanyaan tertutup dan 4 butir pertanyaan terbuka. Analisis data dengan pada 21 pertanyaan tertutup menggunakan persentase jawaban dari responden, sedang jawaban responden pada pertanyaan terbuka dengan kategorisasi jenis tantangan yang dihadapi guru reguler untuk pembelajaran inklusif. Temuan penelitian bahwa kompetensi pedagogi inklusif guru reguler adalah mampu menghadapi keberagaman siswa dari berbagai aspek; guru reguler mampu mengelola kebutuhan belajar beragam siswa; bentuk kompetensi guru reguler untuk pembelajaran bagi siswa slow-learner mampu mengubah konsep abstrak ke dalam bentuk konkret; hambatan yang dirasakan oleh guru reguler mengelola keberagaman siswa; serta tantangan yang dihadapi guru regular untuk melaksanakan pendidikan inklusif terdiri dari: metode mengajar yang beragam, kompetensi memodifikasi pembelajaran, dan pencapaian peningkatan profesional.
\end{abstract}

\section{Kata Kunci: kompetensi pedagogi, tantangan guru, inklusif, slow-learner}

\section{PENDAHULUAN}

Paradigma inklusif di sekolah reguler mengharuskan guru siap menguasai berbagai aspek kompetensi (Dolgova, Kutepova, Kapitanets, Kryzhanovskaya, \& Melnik, 2017;
Hay, 2001). Kesiapan kompetensi guru untuk melaksanakan pendidikan inklusif berarti menguasai kompetensi pedagogi inklusif (Meltz, Herman, \& Pillay, 2014; Myers, 2014; Pantić \& Florian, 2015). Kompetensi pedagogi 
inklusif adalah kompetensi guru memberikan pembelajaran kepada peserta didik dengan atas dasar keberagaman, spesifik untuk siswa disabilitas. Kompetensi ini diperlukan dalam rangka pembelajaran inklusif. Aspek yang harus dikuasai antara lain (1) persepsi tentang strategi instruksional yang tepat; (2) level keberterimaan dan kesiapan untuk mengajar siswa yang disabilitas; (3) kebutuhan pengembangan profesional pembelajaran bagi siswa disabilitas; dan (4) kemampuan kolaborasi antara guru reguler dan guru special education. Guru sekolah reguler perlu memiliki kompetensi pedagogi inklusif (Mcghie-richmond, Irvine, Loreman, Cizman, \& Lupart, 2013; Meltz et al., 2014).

Implikasi terhadap fenomena keberagaman siswa perlu mengembangkan pembelajaran berdiferensiasi (Kirillova \& Faizrakhmanova, 2016). Pengembangan tersebut yang mendasari kompetensi pedagogi inklusif (Beco, 2018; Kirillova \& Faizrakhmanova, 2016; Mcghierichmond et al., 2013). Penguasaan terhadap kompetensi pedagogi inklusif membutuhkan suatu pelatihan bagi guru sekolah reguler (Kirillova \& Faizrakhmanova, 2016; Pantić \& Florian, 2015; Zulfija, Indira, \& Elmira, 2013). Pelatihan bagi guru sekolah reguler tentang pembelajaran inklusif diharapkan memiliki kompetensi melaksanakan pendidikan inklusif (Myers, 2014; Sleeter, 2008.)

Pelatihan bagi guru reguler tentang pendidikan inklusif dikarenakan guru sekolah reguler belum memiliki kepekaan karaktersitik personal guru untuk mengajar disabilitas (Zulfija et al., 2013). Guru sekolah reguler belum memiliki keterampilan khusus untuk strategi mengajar para disabilitas (Tomlinson et al., 2003; Zulfija et al., 2013). Kendala dalam konteks pendidikan inklusif dapat teratasi jika kompetensi inklusif guru sekolah reguler ditingkatkan dengan pelatihan (Hay, 2001). Kebutuhan tentang pelatihan pendidikan inklusif bagi guru sekolah reguler meliputi: (1) pemahaman tentang keberagaman siswa; (2) strategi pembelajaran bagi kelas yang beragam; (3) kompetensi personal menghadapi siswa disabilitas; (4) cultural responsive terhadap siswa disabilitas(Cartledge \& Kourea, 2008; Richards et al., 2003); dan (5) pengembangan kurikulum dan pembelajaran bagi kelas terdapat siswa yang beragam (Haug, 2010; Akhyak, Idrus, \& Bakar, 2013; Ladson-billings, 1999; Tomlinson et al.,
2003). Kelas dengan kondisi siswa beragam membutuhkan pengembangan kurikulum dan pembelajaran berdiferensiasi (Cartledge \& Kourea, 2008; Tomlinson et al., 2003). Permasalahan yang muncul di guru sekolah regular adalah belum siap untuk mengajar anak berkebutuhan khusus(ABK) dan siswa yang beragam, khususnya munculnya fenomena prevalensi yang lebih banyak jenis siswa slowlearner. Kondisi ini menambah permasalahan bagi guru sekolah reguler.

Fenomena kesiapan kompetensi guru sekolah reguler untuk pembelajaran inklusif pada artikel ini diutamakan untuk pembelajaran bagi slow-learner. Fokus ke pembelajaran bagi slow-learner, karena prevalensi siswa berkebutuhan khusus di sekolah dasar yang terbanyak siswa slow-learner. Di sekolah dasar kota Yogyakarta dari enam sekolah dasar yang menjadi pilot project penyelenggara pendidikan inklusi terdapat $64,02 \%$ siswa slow-learner (Juminarsih, 2019). Fenomena data tertinggi jumlah ABK kategori slow-learner menjadi dasar bahwa pelatihan pembelajaran bagi slowlearner.

Peningkatan kompetensi guru untuk pembelajaran bagi slow-learner memberikan efek rasa percaya diri untuk pembelajaran bagi siswa berkebutuhan khusus kategori lainnya (Kaur, Noman, \& Awang-hashim, 2015; Tiwari, Das, \& Sharma, 2015a, 2015b) Fenomena siswa ABK jenis lain yang memiliki problem kognitif, perilaku, dan emosi memberikan tantangan guru dan sebagai kesulitan belajar siswa di sekolah reguler (Kaur et al., 2015; Tiwari et al., 2015a, 2015b). Impkilasi tantangan tersebut bagi guru sekolah reguler adalah dalam pengembangan pembelajaran bagi siswa ABK. Kompetensi tersebut adalah sebuah keterampilan untuk memudahkan slow-learner belajar konsep abstrak melalui penciptaan berbagai kode dan strategi adaptasi perilaku. Keterampilan itu dapat digunakan atau ditransfer untuk keterampilan mengakomodasi pembelajaran ke siswa berkebutuhan khusus jenis lain

Strategi pembelajaran untuk siswa slow-learner dapat dirujuk untuk strategi pembelajaran bagi siswa ABK jenis lain. Siswa ABK jenis lain juga membutuhkan strategi yang hampir sama seperti yang diterapkan pada siswa slow-learner (Baker \& Scanlon, 2016; Oliver \& Barnes, 2010). Strategi pembelajaran itu salah 
satunya strategi pengubahan kode. Strategi untuk mengubah konsep yang abstrak dengan kode yang dipahami slow learner. Misalnya konsep kerja sama dideskripsikan oleh guru dengan bentuk kode perbuatan saling membantu ketika bermain peran. Strategi tersebut menjadi tantangan bagi guru, karena pengubahan kode membutuhkan kreativitas guru. Tantangan berikut bagi guru sekolah reguler bahwa Slowlearner sebagai siswa borderline. (Peltopuro, Ahonen, Kaartinen, Seppälä, \& Närhi, 2014). Makna boderline adalah kemampuan dalam batas di antara rata-rata dan di bawah rata-rata. Kondisi borderline tersebut berimplikasi ada potensi dari slow-learner pada bidang yang praktikal. Potensi yang bagus lebih tepat ke bidang pelajaran praktikal, bukan ke bidang pelajaran akademik tingkat tinggi (Oliver \& Barnes, 2010). Kompetensi yang utama guru untuk pembelajaran kepada siswa slow-learner di antaranya mampu melaksanakan asesmen. Asesmen untuk memutuskan kebutuhan belajar siswa slow-learner. Guru dapat dengan tepat memutuskan kebutuhan belajar siswa slowlearner jika mengetahui karakteristik slowlearner (Alsamiri, 2018; Malik, Rehman, \& Hanif, 2012).

Keputusan kebutuhan belajar dari slowlearner dipergunakan perencanaan pembelajaran. Perencanaan pembelajaran bagi kegiatan belajar siswa slow-learner secara spesifik, maupun kegiatan belajar bagi siswa lainnya. Hal itu perlu perencanaan pembelajaran berdiferensiasi. Perencanaan pembelajaran itu adalah sebuah tantangan baru bagi guru. Tantangan baru permulaaannya menjadi hambatan bagi guru, karena ada beberapa aspek yang perlu penyesuaian. Hal itu dibuktikan dari hasil penelitian tentang hambatan guru melaksanakan kurikulum yang dianggap baru. Hambatan terkait kompetensi yang diperoleh melalui pelatihan dalam waktu singkat, ketersediaan waktu untuk mengembangkan perencanaan pembelajaran dan penilaian (Retnawati, 2015). Penelitian itu menunjukkan bahwa mengembangkan perencanaan sebagai salah satu hambatan ketika melaksanakan kurikulum yang dianggap baru, termasuk mengembangkan perencanaan pembelajaran berdiferensiasi.

Argumentasi dalam melaksanakan inklusif merupakan motivasi dari guru reguler untuk peningkatan kompetensi pedagogi inklusif.
Penggalian terhadap argumentasi melaksanakan inklusif sebagai dasar keputusan materi pelatihan yang dibutuhkan guru untuk melaksanakan inklusif (Chrysostomou \& Symeonidou, 2017). Pengetahuan tentang argumentasi guru reguler melaksanakan inklusi juga untuk mengetahui self-efficacy, tekanan psikologis ketika menghadapi siswa yang beragam signifikan, maupun kepuasan kerja yang menjadi harapan dari guru reguler (Chrysostomou \& Symeonidou, 2017; Katz, 2015). Self-efficacy berguna untuk mengetahui harapan dari guru agar mampu melaksanakan inklusif (Donnell \& Gettinger, 2015; Zainudin, Ashari, \& Kosnin, 2019).

Pengetahuan tentang tekanan psikologis berhadapan dengan siswa beragam signifikan untuk mendorong guru dalam keterampilan pengelompokan siswa di kelas yang beragam. Pengetahuan tentang kepuasan kerja dari guru reguler sebagai dasar untuk ketetapan pencapaian kerja dalam pembelajaran inklusif (Katz, 2015). Ketiga aspek dari self-efficacy, tekanan psikologis, dan kepuasan kerja merupakan aspek yang saling berkaitan untuk keberhasilan pelaksanaan pendidikan inklusif. Aspek itu perlu digarap melalui pelatihan, karena guru sekolah regular perlu menyadari modalitas dari ketiga aspek tersebut sebagai tantangan untuk keberhasilan dalam pembelajaran inklusif.

Pelatihan bagi guru regular dalam rangka solusi terhadap problema guru regular melaksanakan inklusi. Hal tersebut guru regular belum siap mengajar anak berkebutuhan khusus dan mengelola siswa yang beragam; jumlah siswa ABK terbanyak jenis slow-learner di sekolah regular, sehingga perlu kompetensi guru untuk akomodasi belajar bagi slowlearner. Hambatan yang dipersepsi oleh guru reguler adalah perencanaan pembelajaran berdiferensiasi; serta tantangan yang berkaitan dengan aspek self-efficacy, tekanan psikologis, dan kepuasan kerja untuk melaksanakan inklusif. Solusi terhadap problem tersebut perlu dijawab dengan kerja penelitian yang bertujuan: 1) kebutuhan kompetensi pedagogi inklusif dari guru sekolah reguler; 2) persepsi guru reguler untuk mengelola keberagaman siswa; 3) kompetensi yang diperlukan untuk pembelajaran bagi slow-learner; 4) hambatan yang dirasakan oleh guru regular untuk melaksanakan inklusi; serta 5) tantangan yang dihadapi oleh guru reguler untuk melaksanakan inklusi. 


\section{METODE}

Instrumen yang digunakan adalah daftar pertanyaan tertutup sejumlah dua puluh satu (21) item yang perlu direspon dengan pernyataan pilihan mulai tidak sesuai, sesuai, dan sesuai sekali. Hasil dari pernyataan sejumlah 32 responden dipersentasekan yang memilih pernyataan tidak sesuai, sesuai, dan sesuai sekali pada tiap item. Analisis persentase pada tiap item ini untuk mendeskripsikan pernyataan yang paling krusial dalam kompetensi pedagogi inklusif; persepsi untuk melaksanakan pembelajaran berdifferensiasi; kompetensi untuk pembelajaran bagi slow-learner; serta hambatan untuk pembelajaran inklusif. Selanjutnya, daftar pertanyaan terbuka yang diisi oleh responden untuk mengungkap lebih dalam tentang tantangan yang dihadapi guru regular dalam melakasanakan inklusif.

Pertanyaan tertutup dan terbuka disampaikan sesudah guru mengikuti pelatihan tentang pembelajaran inklusif. Pelatihan diselenggarakan oleh Dinas Pendidikan Kota Yogyakarta. Pelatihan dilakukan untuk peningkatan kompetensi guru sekolah regular dalam melaksanakan pembelajaran pendidikan inklusif. Bentuk pelatihan dengan ceramah, tanya jawab, diskusi, dan mencoba untuk berlatih perencanaan pembelajaran sederhana dari kondisi kelas yang beragam. Hasil tersebut perlu diungkap, khusus pendapat dari guru sekolah regular sesudah pelatihan, karena untuk mengetahui aspek krusial tentang pembelajaran inklusif yang perlu ditingkatkan dan diperdalam lagi.

Analisis data pada aspek pertanyaan tertutup dilakukan dengan deskripsi kuantitatif lewat perhitungan persentase untuk mengetahui tingkat persepsi guru dalam tiap aspek kompetensi. Tingkat persepsi guru kategori rendah jika terdapat pada rentang 0-35\%; kategori cukup pada rentang 36\%-65\%; dan kategori tinggi pada rentang 66\%-100\%. Hasil data jawaban guru yang terbuka dihimpun perkategori keberagaman siswa, kerja sama, penggunaan waktu, metode mengajar, dan modifikasi pembelajaran dihitung dengan presentase dan disajikan melalui tabel. Cara ini untuk menampilkan persoalan yang paling sulit dirasakan oleh guru reguler. Analisis data pada pertanyaan terbuka dikategorikan berdasarkan tema. Tema meliputi: self-efficacy, tekanan psikologis, dan kepuasan kerja.

\section{HASIL DAN PEMBAHASAN \\ Hasil}

Pengkajian hasil penelitian untuk menjawab secara berturut-turut tentang problema: kompetensi pedagogi inklusif yang diperlukan guru sekolah reguler; persepsi guru reguler untuk mengelola keberagaman siswa; bentuk kompetensi guru reguler untuk mengakomodasi pembelajaran bagi siswa slowlearner; hambatan yang dirasakan oleh guru reguler; serta tantangan yang dihadapi guru reguler untuk melaksanakan pendidikan inklusi.

Kompetensi pedagogi inklusif guru sekolah reguler disajikan dengan bentuk tabel dari pernyataan guru tentang landasan melaksanakan inklusif pada Tabel 1.

\section{Tabel 1. Respon Guru tentang Landasan} Pedagogi

\begin{tabular}{|c|c|c|c|}
\hline No. & $\begin{array}{l}\text { Aspek Pernyataan Guru } \\
\text { tentang landasan pedagogi }\end{array}$ & Persen & Kategori \\
\hline 1. & $\begin{array}{l}\text { Landasan saya untuk } \\
\text { menghadapi untuk memberi } \\
\text { kesempatan belajar siswa } \\
\text { yang beragam dengan } \\
\text { pandangan humanisme }\end{array}$ & 55,6 & Cukup \\
\hline 2. & $\begin{array}{l}\text { Pandangan lain menghadapi } \\
\text { siswa yang beragam adalah } \\
\text { melaksanakan kebijakan } \\
\text { pemerintah }\end{array}$ & 52,8 & Cukup \\
\hline 3. & $\begin{array}{l}\text { Landasan pedagogis untuk } \\
\text { menghadapi siswa beragam } \\
\text { adalah pemahaman peserta } \\
\text { didik dari berbagai aspek }\end{array}$ & 66.7 & Cukup \\
\hline 4. & $\begin{array}{l}\text { Pendekatan humanisme } \\
\text { adalah mengutamakan siswa } \\
\text { telah beraktualisasi }\end{array}$ & 61,1 & Cukup \\
\hline
\end{tabular}

Kompetensi pedagogi inklusif guru reguler adalah memerlukan pemahaman peserta didik beragam dari berbagai aspek. Untuk itu, kompetensi pedagogi inklusif yang diperlukan guru sekolah regular berdasarkan persepsi guru terhadap keberagaman siswa. Untuk itu, hasil dalam konteks ini selanjutnya disajikan tentang persepsi guru untuk menghadapi keberagaman siswa. Persepsi guru tentang keberagaman siswa merupakan dasar penentuan aspek kompetensi yang perlu digarap dalam pelatihan pembelajaran inklusif bagi guru regular. Persepsi dikaitkan dengan argumen yang diajukan guru sebagai suatu kesulitan tersendiri dan sebagai tantangan untuk melaksanakan pembelajaran inklusif disajikan pada Tabel 2. 
Tabel 2. Persepsi Guru terhadap

\section{Keberagaman Peserta Didik}

\begin{tabular}{rlrl}
\hline No. & Aspek Pernyataan Guru & Persen & Kategori \\
\hline 1. & $\begin{array}{l}\text { Sebelum pelatihan, saya } \\
\text { mengerti bahwa inklusi }\end{array}$ & & \\
& harus mengajar anak yang \\
beragam & 52,8 & Cukup \\
2. $\begin{array}{l}\text { Sesudah pelatihan, tahu } \\
\text { mengajar anak yang } \\
\text { beragam dapat ditata }\end{array}$ & 58,3 & Cukup \\
3. $\begin{array}{l}\text { Saya paham bahwa siswa } \\
\text { yang beragam butuh belajar } \\
\text { yang beragam }\end{array}$ & 77,8 & Tinggi \\
4. $\begin{array}{l}\text { Caranya memberi } \\
\text { akomodasi kebutuhan } \\
\text { belajar siswa yang beragam } \\
\text { dengan kompetensi } \\
\text { berdifferensiasi }\end{array}$ & 48,6 & Cukup \\
\hline
\end{tabular}

Persepsi guru reguler untuk mengelola keberagaman siswa perlu pembelajaran berdiferesiasi. Hal itu perlu keterampilan spesifik, yaitu grading adalah tinggi. Maksudnya responden dari peserta pelatihan frekuensi paling banyak pada respon terhadap pernyataan "Diferensiasi mudah dilaksanakan jika dapat mengelompokan siswa dengan cara menahapkan batas yang dicapai siswa (grading)".

Tabel 3. Kompetensi Pembelajaran Berdiferensiasi

\begin{tabular}{|c|c|c|c|}
\hline No. & Aspek Pernyataan Guru & Persen & Kategori \\
\hline 1. & $\begin{array}{l}\text { Sebelum pelatihan, saya } \\
\text { belum tahu yang dimaksud } \\
\text { pembelajaran berdiferenasi }\end{array}$ & 32,6 & Kurang \\
\hline 2. & $\begin{array}{l}\text { Sesudah pelatihan } \\
\text { pembelajaran } \\
\text { berdiferensiasi mudah } \\
\text { dilakukan }\end{array}$ & 58,5 & Cukup \\
\hline 3. & $\begin{array}{l}\text { Diferensiasi mudah } \\
\text { dilaksanakan jika dapat } \\
\text { mengelompokan siswa } \\
\text { dengan cara menahapkan } \\
\text { batas yang dicapai } \\
\text { siswa(grading) }\end{array}$ & 66,7 & Tinggi \\
\hline 4. & $\begin{array}{l}\text { Diferensiasi belajar siswa } \\
\text { berkebutuhan khusus } \\
\text { dengan pengubahaan kode } \\
\text { yang bervariasi }\end{array}$ & 52,8 & Cukup \\
\hline 5. & $\begin{array}{l}\text { Cara penilaian dengan } \\
\text { pendekatan diferensiasi } \\
\text { tergantung cara belajar } \\
\text { siswa dalam mencapai } \\
\text { tujuan }\end{array}$ & 55,6 & Cukup \\
\hline
\end{tabular}

Komponen kompetensi utama guru reguler dalam konteks pelaksanaan inklusif di kota Yogyakarta pada kompetensi pembelajaran bagi slow-learner. Bentuk kompetensi guru regular untuk mengakomodasi pembelajaran bagi siswa slow-learner direspon oleh guru reguler dengan kategori cukup. Pernyataan yang direspon yang paling tinggi pada kompetensi guru dalam "pembelajaran mengoperasikan angka dengan deskripsi benda dan peristiwa konkrit." Urutan yang berikutnya kompetensi mengembangkan pembelajaran dengan "Diferensiasi dapat mulai dari tema dalam peristiwa kehidupan sehari-hari, kemudian dipelajari dengan pendekatan cara belajar yang berbeda". Data dari hasil tersebut kemudian disajikan pada tabel 4.

\section{Tabel 4. Kompetensi untuk Pembelajaran} bagi Slow Learner

\begin{tabular}{|c|c|c|c|}
\hline No. & Aspek Pernyataan Guru & Persen & Kategori \\
\hline 1. & $\begin{array}{l}\text { Slow learner butuh belajar } \\
\text { dengan aktualisasi bermain } \\
\text { peran dan dramatisasi }\end{array}$ & 61,1 & Cukup \\
\hline 2. & $\begin{array}{l}\text { Slow learner lebih tepat } \\
\text { belajar dengan dipraktekkan } \\
\text { melalui bermain dan } \\
\text { berkolaborasi di bidang seni } \\
\text { dan olah raga }\end{array}$ & 63,9 & Cukup \\
\hline 3. & $\begin{array}{l}\text { Strategi belajar Slow Learner } \\
\text { melalui tahapan kebutuhan } \\
\text { pemecahaan masalah dalam } \\
\text { kehidupan sehari-hari }\end{array}$ & 47,2 & Cukup \\
\hline 4. & $\begin{array}{l}\text { Diferensiasi dapat mulai } \\
\text { dari tema dalam peristiwa } \\
\text { kehidupan sehari-hari, } \\
\text { kemudian dipelajari dengan } \\
\text { pendekatan cara belajar } \\
\text { yang berbeda }\end{array}$ & 62,9 & Cukup \\
\hline 5. & $\begin{array}{l}\text { Diferensiasi dapat } \\
\text { memutuskan skope atau } \\
\text { wilayah cakupan materi dan } \\
\text { cara mencapai tujuan belajar }\end{array}$ & 52,8 & Cukup \\
\hline 6. & $\begin{array}{l}\text { Slow learner dibutuhkan } \\
\text { masa depannya untuk mengisi } \\
\text { pekerjaan yang semi skill dan } \\
\text { memerlukan arahan praktis }\end{array}$ & 50,1 & Cukup \\
\hline 7. & $\begin{array}{l}\text { Slow learner ketika } \\
\text { mengoperasikan angka } \\
\text { dengan deskripsi benda dan } \\
\text { peristiwa konkrit }\end{array}$ & 70,2 & Tinggi \\
\hline 8. & $\begin{array}{l}\text { Kebutuhan pengubahan } \\
\text { koding adalah keterampilan } \\
\text { utama dari guru untuk } \\
\text { mengakomodasi peserta } \\
\text { didik berkebutuhan khusus }\end{array}$ & 55,6 & Cukup \\
\hline
\end{tabular}


Hasil pernyataan guru terhadap kompetensi pembelajaran bagi slow-learner menunjukkan tiap aspek dalam kategori cukup. Hasil itu berimplikasi masih perlu peningkatan kompetensi guru reguler untuk pembelajaran inklusif, khususnya pembelajaran bagi slowlearner. Respon pernyataan dari responden pada nomor 7 dan nomor 4 di tabel nomor 3 menunujukkan juga kompetensi dari guru reguler perlu pelatihan yang lebih intensif. Jadi, kebutuhan guru reguler untuk mengakomodasi pembelajaran bagi slow-learner di sekolah inklusif untuk pelatihan intensif meliputi: model pembelajaran mengoperasikan angka dengan deskripsi benda dan peristiwa konkrit; penetapan tema dalam peristiwa kehidupan sehari-hari, kemudian dipelajari dengan pendekatan cara belajar yang berbeda; bahan yang dipelajari dengan praktek melalui bermain dan berkolaborasi di bidang seni dan olah raga; serta model belajar dengan aktualisasi bermain peran dan dramatisasi.

Kebutuhan peningkatan kompetensi guru terhadap pembelajaran pada slow-learner dalam konteks pembelajaran bagi ABK. Aspek kompetensi modifikasi kurikulum, metode bervariasi, dan strategi pembelajaran bagi slow-learner merupakan kompetensi yang juga diperuntukkan pembelajaran bagi ABK jenis lainnya. Untuk itu, pendalaman terhadap kompetensi guru pada pembelajaran slowlearner dapat dirujuk untuk pembelajaran siswa ABK lainnya. Siswa ABK lainnya sama membutuhkan strategi pengubahaan kode dan adaptasi perilaku. Slow-learner memiliki karakteristik hambatan kognitif yang berakibat keterbatasan belajar akademik dan adaptasi perilaku. Fakta pendukung terdapat pada 8 (delapan) pernyataan di tabel 4.

Hambatan yang dirasakan oleh guru reguler jika akan melaksanakan pembelajaran berdiferensiasi. Pendekatan pembelajaran tersebut sebagai sebuah implikasi untuk mengakomodasi keberagaman siswa di sekolah reguler. Untuk itu, pengakuan guru yang dideskripsikan pada Tabel 5 tentang melaksanakan pembelajaran diferensiasi yang tersulit pada keberagaman siswa, karena kurang tahunya guru tentang strategi pengubahaan kode. Hal itu merupakan tantangan bagi guru dapat melaksanakan pembelajaran berhadapan dengan keberagaman siswa.
Tabel 5. Hambatan yang Dirasakan oleh Guru

\begin{tabular}{lc}
\hline Aspek yang menjadi Alasan & Persentase \\
\hline Keberagaman siswa & 50 \\
Kerjasama dengan berbagai pihak & 3 \\
Keterbatasan waktu & 3 \\
Metode Pengajaran & 18 \\
Modifikasi Pembelajaran & 24 \\
Sarana dan prasarana kurang memadai & 2 \\
\hline
\end{tabular}

Argumentasi kesulitan yang diajukan guru dalam melaksanakan pembelajaran inklusif terdapat enam aspek persoalan disajikan pada tabel 5. Persoalan tersebut menjadi alasan paling sulit adalah keberagaman siswa, Hambatan berikutnya modifikasi pembelajaran, dan metode mengajar.

Selanjutnya, kategori hambatan tersebut karena guru merasa belum mampu atau kompeten. Namun, hambatan itu fenomena berikutnya juga disertai adanya tantangan. Maksudnya ada aspek kompetensi guru regular menganggap sebagai tantangan, karena kompetensi itu masih dapat dicarikan solusi. Aspek tersebut, yaitu memodifikasi pembelajaran; metode mengajar berdiferensiasi; serta peningkatan profesional guru untuk pembelajaran inklusif. Secara berturut-turut disajikan beberapa persoalan yang dianggap tantangan dari guru dalam rangka pembelajaran inklusif. Persoalan dari guru diperoleh dari pernyataan guru ketika mengisi petanyaan terbuka. Persoalan tersebut dikategorikan menjadi tantangan guru reguler, karena penafsiran bahwa mereka masih perlu diberi pelatihan agar mampu menyelesaikan persoalan yang akan dihadapi dalam pembelajaran inklusif. Persoalan dapat dikategorikan pada aspek self-efficacy guru, tekanan psikologis, dan kepuasan kerja. Untuk itu, tantangan guru disajikan dalam bentuk tiga tema, yaitu: aspek self-efficacy guru, tekanan psikologis, dan kepuasan kerja. Tema: 1 selfefficacy guru dengan mengkategorikan dari pernyataan guru tentang metode mengajar berdifferensiasi; tema: 2 tekanan psikokogis mengkategorikan dari pernyataan tentang memodifikasi pembelajaran; dan peningkatan professional guru sebagai kategori tema: 3 kepuasan kerja.

\section{Tema 1: Aspek self-efficacy Guru}

Tema tentang self-efficacy guru adalah hasil yang diperoleh dari pernyataan guru ketika 
mengisi daftar pertanyaan terbuka. Berbagai pernyataan guru tersebut dikategorikan sebagai tantangan self-efficacy guru, karena menyangkut kompetensi mengajar yang dipandang faktor utama keberhasilan melaksanakan pembelajaran di kelas inklusif. Pernyataan itu antara lain disajikan sebagai berikut:

"Ketika guru harus menfokuskan perhatian ke semua murid di kelas dihadapkan harus berbagi perhatian khusus pada peserta didik Anak Berkebutuhan Khusus (ABK). Kesulitan utama menerapkan metode yang sesuai dengan kebutuhan belajar ABK, lebih sulit lagi jika kelas dengan rombongan belajar yang besar"

Pernyataan tersebut menunjukkan bahwa pada guru sekolah reguler mengalami kesulitan dalam pembelajaran berdiferensiasi di sekolah inklusif. Kesulitan terutama pada melaksanakan metode yang beragam, memenuhi kebutuhan belajar siswa yang beragam, dan strategi pengelolaan kegiatan belajar yang beragam dari siswa. Kompetensi khusus yang sulit dilaksanakan membagi perhatian antara siswa yang dipandang sama atau rata-rata dan siswa yang perlu spesifik perhatian intensif seperti perhatian kepada ABK. Selanjutnya, tantangan yang perlu diperhatikan dalam melatih kompetensi guru reguler agar memiliki selfefficacy adalah pernyataan berikut:

"Kami kesulitan membuat kegiatan yang beragam di satu kelas untuk membuat rancangan pembelajaran yang sesuai dengan kebutuhan anaknya; diferensiasi perhatian guru ke semua siswa baik yang non ABK dan $\mathrm{ABK}$; pengelompokam siswa sesuai minatnya; merencanakan pembelajaran disertai evaluasi sesuai kebutuhan siswa."

Pernyataan berikutnya: "Keterbatasan guru melakukan grading, karena siswa harus mengacu pada kurikulum. Demikian juga kesulitan remedialnya; serta tidak adanya pendamping untuk membantu siswa yang butuh bantuan secara spesifik."

\section{Tema 2: Tekanan Psikologis}

Tema 2: Persoalan yang terbanyak dinyatakan oleh peserta pelatihan adalah kesulitan memodifikasi pembelajaran, karena:

"Kondisi lingkungan sekolah, kesesuaian dengan kebutuhan belajar siswa, penentuan yang tepat proses pembelajaran, mendisain pembelajaran dengan modifikasi materi dan memodifikasi kompetensi dasar, ABK bermacam-macam kekhususan, serta penentuan secara holistik kompetensi pengetahuan, sikap, dan keterampilan dalam memodifikasi kurikulum."

Argumentasi tentang kesulitan memodifikasi pembelajaran menunjukkan bahwa guru belum memiliki profesional melaksanakan pembelajaran dengan materi dan metode yang beragam. Kesulitan utama berbagai materi dan metode dapat dikelola menjadi satu tema kegiatan belajar bersama dalam satu kelas.

\section{Tema 3: Kepuasan Kerja}

Tema 3: Argumentasi berikutnya tentang metode mengajar, yaitu kompetensi keterampilan penggunaan keberagaman metode atau cara belajar, serta berbagai cara itu dapat dikolaborasi antar siswa di kelas yang beragam. Hal itu disampaikan oleh guru: "Kesulitan menyediakan beragam cara atau beragam metode untuk mengakomodasi kebutuhan siswa yang beragam, serta pemahaman kepada siswa atau teman yang berbeda dan membutuhkan bantuan."

Kepuasan kerja dari guru dinyatakan bahwa guru perlu ada peningkatan profesional guru. Para guru peserta pelatihan mengajukan alasan bahwa untuk pembelajaran inklusif perlu adanya pelatihan bagi guru sekolah reguler. Mereka mengharapkan adanya bimbingan teknis (Bimtek) dengan argumen: "Pelatihan dan bimtek sangat membantu untuk memberikan kemampuan guru dalam menghadapi ABK".

Selanjutnya, para guru juga menyatakan bahwa peningkatan professional untuk mereka juga memiliki memiliki kompetensi asesmen. Demikian itu dinyatakan oleh mereka "Kompetensi asesmen perlu dimiliki guru dan tidak mudah memberi pengertian pada wali murid tentang hasil asesmen; Adanya asesmen guru dapat benar-benar mengetahui kondisi siswanya sehingga guru dapat memperlakukan siswanya sesuai dengan kondisi siswanya; Asesmen disesuaikan dengan instrumen informalnya, materi harus dicari dari beberapa sumber yang baik dan teruji secara terupdate, kolaborasi siswa diperhatikan dalam menciptakan suasana pembelajaran yang sangat baik tanpa membedabedakan teman; Dalam pembelajaran dalam kelas kita telah mengetahui keberagaman dalam kelas dan jangan membedakan siswa yang satu dengan yang lain, menganggap semua anak sama." 
Harapan guru untuk peningkatan professional melaksanakan pembelajaran inklusif juga diperkuat lagi beberapa pernyataan dari guru lainnya: "Guru profesional dalam pembelajaran inklusif harus dapat melakukan asesmen bagi siswa $\mathrm{ABK}$, dilanjutkan dengan memodifikasi materi yang sesuai untuk siswa ABK, berkolaborasi dengan siswa yang dinilai mampu untuk tutor sebaya. Selain itu untuk peningkatan profesional guru inklusif adalah dengan mencari solusi bagi siswa maupun orangtua dalam menangani dan menyembuhkan siswa ABK yang temporer. Guru profesional dalam pembelajaran secara inklusif adalah seorang guru yang dapat memahami suatu keadaan dalam diri dan kebutuhan siswasiswanya. Perlu adanya guru pendamping atau mengadakan pendekatan-pendekatan berbagai ahli."

Poin utama hasil penelitian dari guru reguler peserta pelatihan meliputi: bahwa kompetensi pedagogi inklusif merupakan kesadaran menghadapi keragaman siswa yang dipandang dari berbagai aspek; persepsi guru bahwa: "Diferensiasi mudah dilaksanakan jika dapat mengelompokan siswa dengan cara menahapkan batas yang dicapai siswa (grading)". Bentuk kompetensi guru reguler untuk mengakomodasi pembelajaran bagi siswa slow-learner adalah mengoperasikan konsep abstrak dengan deskripsi benda dan peristiwa konkrit; hambatan yang paling dirasakan paling sulit oleh guru reguler adalah keberagaman siswa; serta tantangan yang dihadapi guru pada aspek self-efficacy tentang metode mengajar yang beragam, aspek tekanan psikologis adalah kesulitan memodifikasi pembelajaran, dan kepuasan kerja jika profesional guru tercapai.

\section{Pembahasan}

Tujuan tersebut berlatar belakang dari masalah guru reguler belum siap mengajar anak berkebutuhan khusus dan mengelola siswa yang beragam; jumlah terbanyak siswa ABK jenis slow-learner di sekolah reguler, sehingga perlu kompetensi guru untuk akomodasi belajar bagi slow-learner. Hambatan yang dipersepsi oleh guru reguler adalah perencanaan pembelajaran berdiferensiasi; serta tantangan yang berkaitan dengan aspek self-efficacy, tekanan psikologis, dan kepuasan kerja untuk melaksanakan inklusif. Berdasarkan tujuan dan latar belakang masalah tersebut bahwa hasil penelitian yang perlu didiskusikan/dibahas meliputi: bahwa kompetensi pedagogi inklusif guru reguler adalah mampu menghadapi keberagaman siswa dari berbagai aspek; kemampuan guru reguler mengelola kebutuhan belajar beragam siswa; bentuk kompetensi guru reguler untuk pembelajaran bagi siswa slow-learner mampu mengubah konsep abstrak ke dalam bentuk konkrit; hambatan yang dirasakan oleh guru reguler mengelola keberagaman siswa; serta tantangan yang dihadapi guru reguler untuk melaksanakan pendidikan inklusi terdiri dari: metode mengajar yang beragam, kompetensi memodifikasi pembelajaran, dan pencapaian peningkatan profesional.

Kompetensi pedagogi inklusif guru reguler terjawab dari hasil adalah mampu mengelola keberagaman siswa dari berbagai aspek. Hal itu juga ditunjukkan dari persepsi guru untuk pembelajaran berdiferensiasi di sekolah inklusif adalah terkait keberagaman siswa kategori tinggi. Pengetahuan guru itu adalah keberagaman siswa yang terkait beragamnya ABK yang akan dihadapi. Fenomena itu sudah menjadi hal yang melekat pada pikiran guru reguler bahwa melaksanakan inklusif sulit jika berhadapan dengan ABK yang beragam. Fenomena ini terjadi dikarenakan guru sekolah reguler belum dipersiapkan untuk memiliki sensitivitas personal untuk mengahadapi disabilitas (Zulfija et al., 2013). Semua calon guru sudah dibekali pengetahuan kompetensi pedagogi tentang keberagaman peserta didik. Namun, guru reguler belum dibekalinya kompetensi mengajar bagi disabilitas menjadi suatu kesulitan untuk berhadapan dengan keberagaman siswa (Tomlinson et al., 2003). Khususnya beragam yang secara individual berbeda signifikan. ABK adalah fenomena individu berbeda secara signifikan dalam hal kemampuan. Fenomena ini mengharuskan guru memiliki kompetensi pembelajaran berdiferensiasi ketika berhadapan dengan ABK (Cartledge \& Kourea, 2008).

Kompetensi pembelajaran berdiferensiasi ketika guru sudah mendapatkan pelatihaan merasa mudah melaksanakan. Diferensiasi dengan melakukan penahapan/grading sebagai dasar pengelompokan siswa (Tomlinson et al., 2003). Kompetensi untuk melaksanakan diferensiasi juga perlu dukungan kompetensi merespon konteks budaya terhadap siswa disabilitas (Cartledge \& 
Kourea, 2008; Richards et al., 2003). Kompetensi itu merupakan keterampilan untuk menghargai dan mengembangkan perilaku sosial antar siswa beragam budaya. Keberagaman budaya dari siswa disabilitas merupakan persoalan yang perlu dipahami oleh guru reguler. Keberagaman budaya menjadi hambatan ketika berinteraksi sosial antar siswa disabilitas di kelas. Persoalan itu perlu dipahami oleh guru untuk mencari solusi di dalam cara belajar sesuai dengan cara budaya yang dianut oleh siswa disabilitas.

Kompetensi pembelajaran berdiferensiasi perlu juga kompetensi guru untuk pengubahaan kode yang beragam. Kode adalah alat penyampaian pesan dalam interaksi pembelajaran antar guru-siswa dan antar siswa. Pengubahan kode mengharuskan guru juga terampil kode dari ragam budaya. Dukungan kompetensi tersebut juga berguna bagi guru mengeksplor potensi dari siswa disabilitas (Kaur et al., 2015; Tiwari et al., 2015a, 2015b). Pada akhir dekade ini bahwa siswa yang problem kognitif, perilaku atau emosi sebagai tantangan kesulitan belajar di kelas inklusif (Kaur et al., 2015). Problem utama pada siswa hambatan kognitif adalah pemahaman kode. Untuk itu, kompetensi untuk pembelajaran bagi siswa slow learner berimplikasi juga pada kompetensi pembelajaran bagi siswa ABK jenis lain, khususnya dalam strategi pengubahan kode.

Kompetensi pembelajaran bagi slow learner pada aspek pengubahan kode kategori cukup. Tetapi, kompetensi pengoperasian angka dengan deskripsi benda dan peristiwa konkrit kategori tinggi. Kedua fenomena itu sebenarnya saling berhubungan, namun guru belum paham bahwa substansi pembelajaran untuk memahami dan menerapkan pengetahuan adalah melalui kode. Keterampilan mengolah kode merupakan hambatan yang dimiliki siswa slowlearner (Baker \& Scanlon, 2016). Solusi terhadap pembelajaran bagi slow-learner adalah keterampilan guru mengubah kode semua substansi pengetahuan secara konkrit. Kompetensi itu dapat juga digunakan untuk solusi problem pembelajaran bagi ABK lainnya.

Kompetensi berikutnya yang kategori cukup urutan berikutnya adalah pengakuan guru pada aspek pembelajaran praktis. Pembelajaran dilaksanakan dengan bermain dan kolaborasi dengan guru olah raga dan seni. Kebutuhan kompetensi pada aspek tersebut dikarenakan kebutuhanbelajarslowlearnerpadapembelajaran yang substasi materi ke arah konkrit dan praktis. Slow learner terhambat untuk belajar bidang akademis, namun berprestasi untuk bidang seni dan olah raga. Implikasi kondisi borderline tersebut berakibat juga pada kemampuan belajar yang abstrak terbatas, tetapi masih dapat berprestasi pada bidang yang nonakademis (Peltopuro et al., 2014). Jumlah terbanyak dari jenis ABK lainnya diduga gejala perilaku yang tidak dapat diamati sebagai implikasi boderline. Untuk itu, kompetensi guru juga kemampuan mengidentifikasi secara tepat agar supaya tepat memberikan arah pembelajaran (Alsamiri, 2018).

Kompetensi guru pada pembelajaran slow-learner perlu konteks tema kehidupan sehari-hari juga sebagai kebutuhan solusi pada hambatan kognitifnya (Peltopuro et al., 2014). Hambatan kognitif pada slow learner berakibat lambat untuk mengubah fakta-fakta pengetahuan ke dalam bentuk komunikasi kode. Untuk itu, pemahaman karakteristik slow learner sangat diperlukan guru. Karakteristik berguna untuk asesmen kebutuhan belajar dan arah belajar untuk masa depan slow-learner (Alsamiri, 2018).

Kompetensi pedagogi inklusif guru reguler adalah menghadapi keberagaman siswa dari berbagai aspek. Hal itu membuktikan bahwa guru sudah menyadari bahwa untuk melaksanakan inklusif perlu kompetensi pedagogie yang perlu dikuasai. Penguasaan pedagogi inklusif oleh guru terkait tantangan yang dihadapi guru dan merasa paling sulit berhadapan dengan keberagaman peserta didik di kelas inklusif. Pelatihan untuk peningkatan pedagogie inklusif adalah pendalaman tentang karakteristik peserta didik, khususnya karakteristik ABK (Meltz et al., 2014; Myers, 2014; Pantić \& Florian, 2015; Pintrich, 2003). Pemahaman tetang karakteristik dan melakukan pendekatan motivasi kepada siswa disabilitas sebagai suatu keterampilan dalam penguasaan kompetensi pedagogi inklusif. Pendukung penguasaan pedagogie inklusif adalah sensitivitas personal guru menghadapi disabilitas dan cultural responsive dalam menghadapi siswa disabilitas (Cartledge \& Kourea, 2008; Richards et al., 2003). Sensitivitas personal guru maknanya guru memiliki kepekaan tahu terhadap kebutuhan belajar siswa disabilitas, cara belajar, harapan di dalam belajar, serta harapan yang dibangun dari latar 
belakang keluarga. Kepekaan itu bersandingan dengan cultural responsive. Maknanya untuk mampu sensitif terhadap kebutuhan belajar siswa disabilitas atas dasar tahu cara merespon siswa secara individual berdasarkan latar belakang budaya siswa disabilitas.

Keberagamansiswapalingtinggipersentase dirasakan sulit oleh guru. Fakta itu menunjukkan bahwa kompentensi pedagogie inklusif merupakan tantangan di dalam peningkatan. Keberagaman siswa perlu dilakukan guru dengan mendengarkan cerita dari para siswa tentang dirinya maupun temannya dalam perspektif siswa. Pandangan tentang pendidikan inklusi harus didekati dengan konstruk sosial dan hak asasi manusia (Chrysostomou \& Symeonidou, 2017). Sikap terhadap keberagaman siswa adalah cerminan kehidupan dalam masyarakat. Masing individu dapat berperan sesuai potensi dan juga dapat dikolaborasi antar siswa. Untuk itu, guru reguler perlu mendalami inklusi dalam perspective konstruk sosial dan hak asasi manusia. Paradigma berpikir dari pendalaman itu berguna untuk memandang tentang fakta keberagaman siswa.

Tantangan guru terhadap keberagaman siswa adalah kompeten dalam pembelajaran berdiferensiasi. Tantangan ini merupakan suatu paradigma dalam inovasi dalam pembelajaran. Guru memang memiliki kewajiban untuk selalu memperbaharui dalamkewajiban profesionalnya. Hambatan di dalam melaksanakan inklusi adalah hambatan yang wajar di dalam tugas profesional lainya (Retnawati, 2015). Hambatan itu merupakan tantangan yang dicarikan solusinya dengan pelatihan peningkatan profesional guru dalam pembelajaran inklusif (Hay, 2001).

Tantangan berikutnya adalah masalah kesulitan metode mengajar yang beragam dan modifikasi kurikulum. Tantangan tersebut berkaitan dengan self-efficacy guru, jika tidak dikuasai menjadi tekanan psikologis (Alsamiri, 2018; Chrysostomou \& Symeonidou, 2017; Retnawati, 2015). Kedua aspek itu perlu dicari solusi sebagai materi pelatihan yang utama. Jadi, materi utama peningkatan profesional guru dalam pembelajaran inklusif adalah tentang penggunaan metode yang beragam dan modifikasi kurikulum. Aspek kompetensi pedagogie harus didukung oleh penguasaan (1) persepsi tentang strategi instruksional yang tepat; (2) level keberterimaan dan kesiapan untuk mengajar siswa yang disabilitas; (3) kebutuhan pengembangan profesional pembelajaran bagi siswa disabilitas; dan (4) kemampuan kolaborasi antara guru reguler dan guru special education (Mcghie-richmond et al., 2013; Meltz et al., 2014). Dua aspek itu penting dalam penyusunan materi pelatihan sebagai pendamping kompetensi pemahaman keberagaman peserta didik, khususnya pada disabilitas.

Tantangan yang harus dihadapi guru dalam peningkatan profesional dalam pembelajaran inklusif dengan mengetahui tahapan dalam pembelajaran inklusif. Hal tersebut sudah diakui oleh guru dan berharap untuk kompeten dalam pembelajaran inkusif memiliki kompetensi melakukan asesmen bagi siswa ABK, dilanjutkan dengan memodifikasi materi yang sesuai untuk siswa ABK, berkolaborasi dengan siswa yang dinilai mampu untuk tutor sebaya. Selain itu untuk peningkatan profesional guru inklusif adalah dengan mencari solusi bagi siswa maupun orangtua dalam menangani dan menyembuhkan siswa $\mathrm{ABK}$ yang temporar. Kondisi itu sebagai pendekatan dari harapan guru dalam pembelajaran inklusif, jika tercapai menjadi capaian kepuasan guru (Chrysostomou \& Symeonidou, 2017).

Pelatihan bagi guru sekolah regular amat krusial. Namun, pelatihan yang dilaksanakan baru taraf awal untuk mengenalkan pengetahuan tentang pembelajaran berdifferensiasi di sekolah regular penyelenggara inklusif. Penelitian tentang kompetensi pada taraf sesudah pelatihan baru pada taraf menggali kesadaran tentang kepekaan karaktersitik personal guru untuk mengajar disabilitas (Zulfija et al., 2013). Untuk itu, masih menjadi tantangan bagi guru tentang self-efficacy dalam melaksanakan pembelajaran inklusif. Tantangan ini masih perlu pelatihan tingkat lanjut dengan diperdalam pada kompetensi spesifik agar supaya guru dapat mengurangi tekanan psikologis dan peningkatan profesional memiliki kepekaan karaktersitik personal guru untuk mengajar disabilitas (Donnell \& Gettinger, 2015; Zainudin et al., 2019).

\section{KESIMPULAN}

Kompetensi guru inklusif bagi slow learner adalah kompetensi pedagogi inklusif dengan pendukung kompetensi pembelajaran dengan peserta didik beragam yang dikenal 
dengan berdiferensiasi melalui kegiatan modifikasi kurikulum, metode mengajar yang beragam. Hambatan yang dialami oleh guru yaitu pengelolaan pembelajaran berdiferensiasi dan self-efficacy guru. Tantangan yang perlu dikuasai yakni pembelajaran berdiferensiasi untuk merencanakan, mengelola dan menilai pembelajaran dengan memperhatikan keberagaman karakteristik siswa melalui modifikasi kurikulum, akomodasi pembelajaran, penggunaan berbagai metode dan media. Tantangan yang utama peningkatan profesional guru adalah mengelola keberagaman siswa di kelas inklusif dengan terampil asesmen, pembelajaran berdiferensiasi, metode mengajar yang beragam, dan modifikasi kurikulum .Bentuk pembelajaran berdiferensiasi lainnya bagi slowlearner yaitu pengubahan kode abstrak menjadi konkrit, penetapan tema sesuai konteks dalam kehidupan sehari-hari. Pemahaman tentang keberagaman karakterstik peserta didik perlu didukung oleh kompetensi guru tentang konstruk sosial dan hak asasi dari pandangan disabiltas, serta cultural responsive.

\section{REFERENCES}

Akhyak, A., Idrus, M. \& Bakar, Y. A. (2013). Implementation of teachers pedagogy competence to optimizing learners development in public primary school in Indonesia. Journal education and research, 1(9), 113-122. http://repo.iaintulungagung.ac.id/3280/.

Alsamiri, Y. (2018). How learning disabilities teachers in the Kingdom of Saudi Arabia define students with giftedness and learning disabilities. Cakrawala Pendidikan, 37(3), 356-365. doi:10.21831/cp.v38i3.21566.

Baker, D., \& Scanlon, D. (2016). Student perspectives on academic accommodations. Exceptionality: A Special Education Journal, 24(2), 93-108. doi:10.1080/09362835.2015.1064411.

Beco, D. (2018). The right to inclusive education: Why is there so much opposition to its implementation? International Journal of Law in Context, 143(3), 396-415. doi:10.1017/51744552317000532.
Cartledge, G., \& Kourea, L. (2008). Culturally Responsive Classrooms for Culturally Diverse Students With and At Risk for Disabilities, Exceptional Children. 74(3), 351-371.doi. org/10.1177/001440290807400305.

Chrysostomou, M., \& Symeonidou, S. (2017). Education for disability equality through disabled people's life stories and narratives: working and learning together in a school-based professional development programme for inclusion. European Journal of Special Needs Education, 32(4), 572-585. doi:10.1080/0 8856257.2017 .1297574 .

Dolgova, V. I., Kutepova, N. G., Kapitanets, E. G., Kryzhanovskaya, N. V, \& Melnik, E. V. (2017). The study of motivational readiness of teachers to implement inclusive education of children with disabilities. Espacios, 38(40), 9-15.https:// www.revistaespacios.com/a17v38n40/ a17v38n40p09.pdf.

Donnell, L. A., \& Gettinger, M. (2015). Elementary school teachers' acceptability of school reform: Contribution of belief congruence, self-efficacy, and professional development. Teaching and Teacher Education, 51(2015), 47-57. doi:10.1016/j.tate.2015.06.003.

Haug, P. (2010). Approaches to empirical research on inclusive education. Scandinavian Journal of Disability Research, 12(3), 199209. doi:10.1080/15017410903385052.

Hay, J. F. (2001). Teacher preparedness for inclusive education. South African Journal of Education, 21(4), 213-218. https://www.ajol.info/index.php/saje/ article/view/24905/20517.

Juminarsih, R. W. (2019). Pencapaian standar pelayanan minimal (SPM) sekolah dasar inklusi kota Yogyakarta. Skripsi. Yogyakarta: Fakultas Ilmu Pendidikan Universitas Negeri Yogyakarta. 
Katz, J. (2015). Implementing the three block model of universal design for learning: Effects on teachers' self-efficacy, stress, and job satisfaction in inclusive classrooms K-12. International Journal of Inclusive Education, 19(1), 1-20. doi:10.1 080/13603116.2014.881569.

Kaur, A., Noman, M., \& Awang-hashim, R. (2015). Exploring strategies of teaching and classroom practices in response to challenges of inclusion in a Thai school : a case study. International Journal of Inclusive Education, 20(5), 474-485. doi :10.1080/13603116.2015.1090489.

Kirillova, E. A., \& Faizrakhmanova, A. T. (2016). Teaching staff training for work in the context of inclusive education. IEJME -Mathematics Education, 11(4), 647-656. https://www.iejme.com/article/teachingstaff-training-for-work-in-the-context-ofinclusive-education.

Ladson-billings, G. J. (1999). Preparing teachers for diverse student populations: A critical race theory perspective. Review of research in education, 24(1), 211-247. doi:10.3102/0091732X024001211.

Malik, N.I., Rehman, G., \& Hanif,R. (2012). Effect of acsdemic interventions on the developmental skills of Slow Learner. Pakistan Journal of Psychological Research. 27(1). 135-151. http://ezpprod1.hul.harvard.edu/login?url=http:// search.ebscohos.

Mcghie-richmond, D., Irvine, A., Loreman, T., Cizman, J. L., \& Lupart, J. (2013). Teacher perspectives on inclusive education in Rural Alberta, Canada. Canadian Journal of Education, 36(1), 195-239. http:// journals.sfu.ca/cje/index.php/cje-rce/ article/download/1155/1470/.

Meltz, A., Herman, C., \& Pillay, V. (2014). Inclusive education: A case of beliefs competing for implementation. South African Journal of Education, 34(3), 1-8. doi:10.15700/201409161049.
Myers, M. (2014). Students with disabilities: Perspectives of regular education teachers of increased inclusion (Dissertation, East Tennessee State University). https:// dc.etsu.edu/etd.

Oliver, M., \& Barnes, C. (2010). Disability studies, disabled people and the struggle for inclusion. British Journal of Sociology of Education, 31(5), 547-560. doi:10.1080 /01425692.2010.500088.

Pantić, N., \& Florian, L. (2015). Developing teachers as agents of inclusion and social justice. Education Inquiry, 6(3), 333-351. doi:10.3402/edui.v6.27311.

Peltopuro, M., Ahonen, T., Kaartinen, J., Seppälä, H., \& Närhi, V. (2014). Borderline intellectual functioning: A systematic literature review. Intellectual and Developmental Disabilities, 52(6), 419443. doi:10.1352/1934-9556-52.6.419.

Pintrich, P. R. (2003). A motivational science perspective on the role of studentmotivation in learning and teaching contexts. Journal of Educational Psychology, 95(4), 667686. doi:10.1037/0022-0663.95.4.667.

Retnawati, H. (2015). Hambatan guru matematika sekolah menengah pertama dalam menerapkan kurikulum baru. [The obstacles of junior high school mathematics teachers in implementing the new curriculum]. Cakrawala Pendidikan, 3(3), 390-403. doi:10.21831/ cp.v3i3.7694.

Richards, H. V, Brown, A. F., \& Forde, T. B. (2003). Addressing Diversity in Schools : Culturally Responsive Pedagogy.

Sleeter, C. (2008). An invitation to suport diverse students. Journal of Teacher Education. Vol 59(3).doi. org/10.1177/0022487108317019

Tiwari, A., Das, A., \& Sharma, M. (2015a). Inclusive education a "rhetoric" or "reality"? Teachers' perspectives and beliefs. Teaching and Teacher Education, 
52(2015), 128-136. doi:10.1016/j. tate.2015.09.002.

Tiwari, A., Das, A., \& Sharma, M. (2015b). Inclusive education a "rhetoric" or "reality"? Teachers' perspectives and beliefs. Teaching and Teacher Education, 52(2015), 128-136. doi:10.1016/j. tate.2015.09.002.

Tomlinson, C. A., Brighton, C., Callahan, C. M., Moon, T. R., Brimijoin, K., Conover, L. A., \& Reynolds, T. (2003). Differentiating Instruction in Response to Student Readiness, Interest, and Learning Profile in Academically Diverse Classrooms: A Review of Literature. Journal for The Education of The Gifted. 27(2), 119-145. doi.0rg/10.1177/01635320302700203.
Zainudin, N. F. B., Ashari, Z. B. M, \& Kosnin, A. B. (2019). A concept paper: The effectiveness of project based learning on self-efficacy's level among slow learner students in Malaysia. Education, Sustainability and Society, 2(3), 21-24. doi:10.26480/ess.03.2019.21.24.

Zulfija, M., Indira, O., \& Elmira, U. (2013). The professional competence of teachers in inclusive education. Procedia-Social and Behavioral Sciences, 89(2013), 549-554. doi:10.1016/j.sbspro.2013.08.892. 